\title{
Use of water from small alluvial aquifers for irrigation in semi-arid regions ${ }^{1}$
}

\section{Uso das águas de pequenos aquíferos aluviais para irrigação nas regiões semiáridas}

\author{
Julien Daniel Pierre Burte ${ }^{2 *}$, Anne Coudrain ${ }^{3}$ e Serge Marlet $^{4}$
}

\begin{abstract}
Water from small alluvial aquifers constitutes an attractive and low-cost option for irrigation and rural development in Northeastern Brazil. Based on piezometric measurements, geochemical analyses and electrical conductivity estimates, the present case study identified the main processes determining the hydrosaline dynamics of an alluvial aquifer in a small watershed inserted in the crystalline bedrock of a semi-arid region in Ceará and evaluated the availability of water for irrigation. Accumulation of salts in soil are related to evaporative flux from the aquifer and is increased by irrigation from the groundwater of the alluvial aquifer. The water in these aquifers may be used for irrigation, but represents a risk of soil salinization and alkalinization. Integrated management of surface and underground water resources in the Forquilha watershed may help control irrigation water quality (salinity and residual alkalinity), thereby rationalizing the use of local reservoirs and minimizing losses from evaporation. It has to take into account the complex dynamic of salts and water between the reservoirs, release of water into the river, floods and irrigations.
\end{abstract}

Key words - Salinity. Groundwater. Irrigation.

\begin{abstract}
Resumo - A agricultura irrigada a partir da água subterrânea dos pequenos aqüíferos aluviais é uma alternativa interessante e de baixo custo para o desenvolvimento do meio rural no Nordeste brasileiro. A partir de um estudo de caso numa micro-bacia no centro da área cristalina do semiárido cearense é analisada a contribuição de características físicas (piezometria), geoquímicas e de modelos (de balanço hidrológico e de massa) para identificar a origem e os principais processos que governam a dinâmica da salinidade das águas de um pequeno aqüífero aluvial e avaliar a disponibilidade de água para irrigação. A irrigação conduz a uma redistribuição dos sais da zona saturada para a zona não saturada do aqüífero, podendo ocorrer acumulação. Devido as suas características, as águas do aqüífero aluvial podem ser usadas para a irrigação, entretanto, existe certo grau de risco de salinização e sodificação dos solos. O manejo integrado das águas superficiais e subterrâneas da bacia permite controlar a qualidade da água (salinidade e sodicidade residual) disponibilizada para a irrigação, permitindo ainda um melhor aproveitamento das águas dos açudes e limitando as perdas por evaporação. Ele deve levar em conta a dinâmica complexa da água e dos sais entre os reservatórios, as liberações de água no rio, as cheias e as irrigações.
\end{abstract}

Palavras-chave - Salinidade. Água subterrânea. Irrigação.

\footnotetext{
* Autor para correspondência

${ }^{1}$ Recebido para publicação em 31/08/2010; aprovado em 31/01/2011

Trabalho submetido e selecionado no primeiro Simpósio Brasileiro de Salinidade realizado de 12-15/10/2010 em Fortaleza, Ceará, Brasil; Financial support received from FUNCEME, CNPQ and CAPES-COFECUB for the doctorate study in water resources of Julien D. P. Burte ${ }^{2}$ Programa de Pós-Graduação em Engenharia Agrícola, CCA/UFC, Caixa Postal 12.168, 60455-970, Fortaleza-CE, Brasil, julienburte@gmail.com ${ }^{3}$ Institut de Recherche pour Le Développement-IRD, Montpellier, France, anne.coudrain@ird.fr

${ }^{4}$ Centre International de Recherche Agronomique-CIRAD, UMR G-EAU, Montpellier, France, serge.marlet@cirad.fr
} 


\section{Introduction}

Small alluvial aquifers represent an alternative water resource for irrigation and development of semi-arid regions in Northeastern Brazil. Manually perforated wells in such aquifers can supply water of reasonable quality at low cost to settlements traditionally restricted to river banks. The adequate use of all available water resources for agricultural purposes is a prerequisite for sustainable rural development (MONTENEGRO et al., 2010).

The low evaporation flux in these small aquifers a few millimeters per year (COUDRAIN-RIBSTEIN et al., 1998) is a particularly interesting feature for water supply in regions with high rainfall deficit (annual rainfall is approximately $700 \mathrm{~mm}$, compared to over $2000 \mathrm{~mm}$ in evapotranspiration). Due to the large spatial and temporal heterogeneity of rainfall and the prevalence of shallow soils, runoff is intermittent and water tends to be scarce (CADIER, 1996). However, the use of alluvial aquifers for irrigation (BASTOS, 2009; MONTENEGRO et al., 2010) and domestic water supply is often compromised by excessive salinity. Since surface runoff, the main source of aquifer recharge (BURTE et al., 2005), is generally of low salinity (total dissolved solids $\sim 0.1 \mathrm{~g} \mathrm{~L}^{-1}$ ), in most of the semi-arid Northeast the water salinity of alluvial aquifers $\left(\sim 0.7 \mathrm{~g} \mathrm{~L}^{-1}\right)$ lies between that of reservoir water $\left(\sim 0.2 \mathrm{~g} \mathrm{~L}^{-1}\right)$ and groundwater in the crystalline bedrock $\left(\sim 2 \mathrm{~g} \mathrm{~L}^{-1}\right)$ (AUDRY ; SUASSUNA, 1995; SALES NETO, 2002).

The primary objective of this study was to use piezometric measurements, chemical analyses and electrical conductivity estimates to identify the main processes determining the hydrosaline dynamics of an alluvial aquifer in a small watershed inserted in the crystalline bedrock of a semi-arid region in Ceará and evaluate the availability of water for irrigation. Secondarily, the study looks at the role of integrated water resources management in the control of irrigation water salinity and its impact on soils and plants.

\section{Materials and methods}

The study area is located in the Forquilha watershed ( $5^{\circ} 17^{\prime} \mathrm{S}$; $\left.39^{\circ} 30^{\prime} \mathrm{W}\right)$ which covers $220 \mathrm{~km}^{2}$ of the municipality of Quixeramobim (Ceará, Brazil) (FIG. 1).

In this region the hydrological dynamics of the alluvial aquifer are determined by seasonal surface runoff. Because of shallow soils, runoff primarily takes the form of Hortonian overland flow. Runoff is only observed after the first heavy rainfalls of the rainy season. Most runoff in

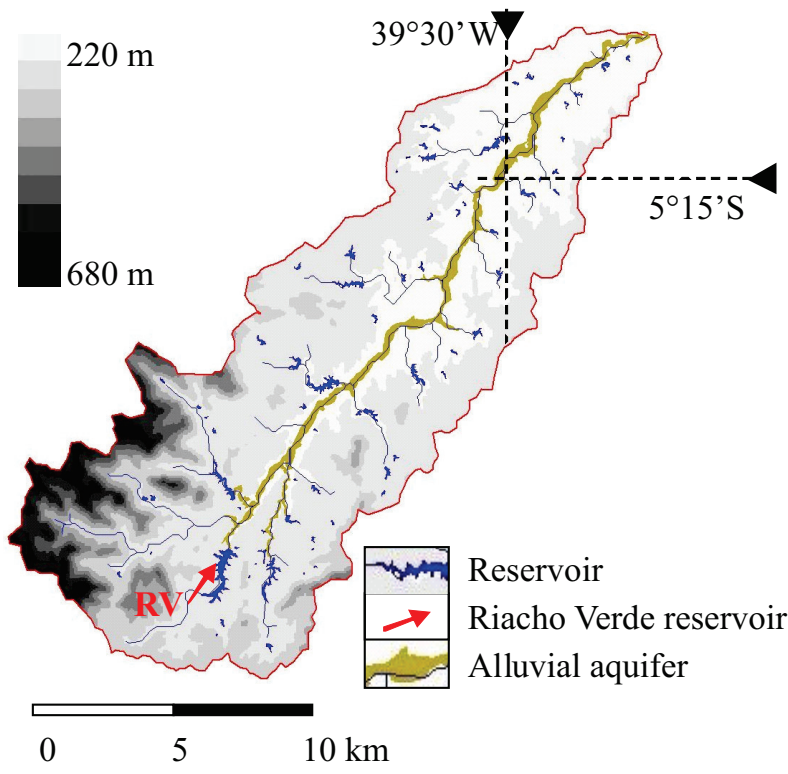

Figure 1 - The Forquilha watershed and its main surface and underground water resources

this period comes from intense rainfall events followed by periods without precipitation of variable duration (1 day to 2 months). Over the past decade, the manual drilling of shallow wells $(<10 \mathrm{~m})$ in the alluvial aquifer has contributed to the development of small-scale $(<5 \mathrm{ha}$ ) irrigated forage and horticultural fields. However, irrigation restrictions due to the salinity of the alluvial groundwater appeared after 2-3 years of crops, leading local farmers in search of other sources of water for irrigation. Since 2005 the large volume of water stored in the Riacho Verde reservoir (RV in FIG. 1) has made it possible to release water into the Forquilha river during the dry season, making it perennial down to the end of Section 2 (FIG. 2).

Geochemical analysis - The main characteristics and seasonal variability of the geochemical composition of the groundwater were evaluated by piezometric monitoring and chemical analyses of water samples : 160 water samples were collected for chemical analysis from the Forquilha river, reservoirs, shallow wells in the alluvial aquifer and deep wells in the crystalline aquifer. Sampling was done during the dry season (July 1999; September 2003; October 2003; January 2004; September 2004; October 2004; December 2004; October 2005), by the end of the rainy season (July 2003; June 2004; July 2004; May 2005) and during the exceptionally heavy rainy season of 2004 (February-May) (ALVES et al, 2006). The samples were analyzed for $\mathrm{Ca}^{2+}$, $\mathrm{Mg}^{2+}, \mathrm{Na}^{+}, \mathrm{Cl}^{-}, \mathrm{SO}_{4}{ }^{2-}, \mathrm{HCO}_{3}^{-}, \mathrm{CO}_{3}{ }^{2-}, \mathrm{NO}_{3}^{-}$, total $\mathrm{Fe}, \mathrm{SiO}_{2}$, $\mathrm{pH}$ and electrical conductivity (EC). In addition, the level 


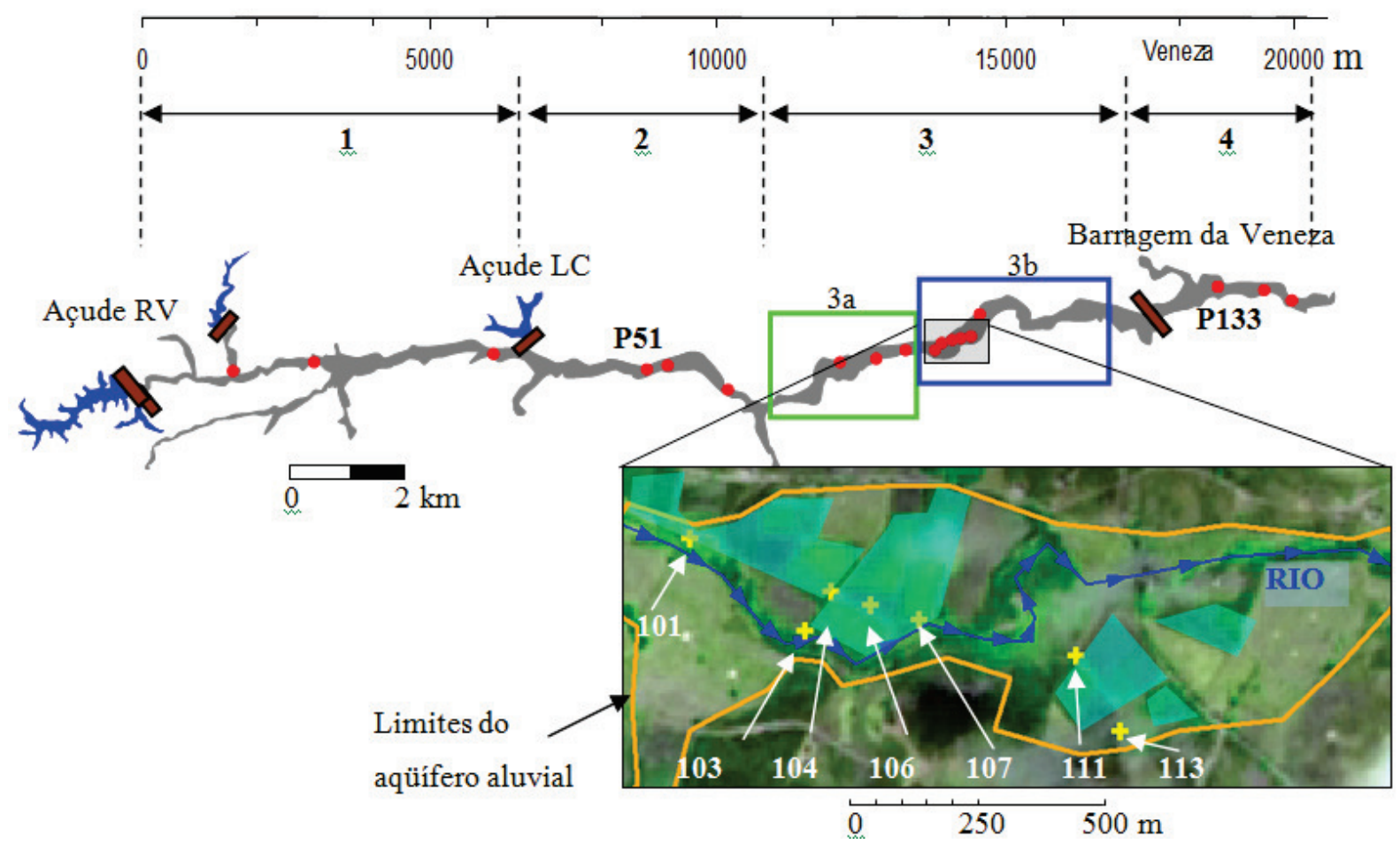

Figure 2 - Main water resources (reservoirs and aquifers) of the Forquilha watershed. The abscissa indicate distance from the Riacho Verde Reservoir measured along the river bed. The area was divided in sectors $(1 ; 2 ; 3$ and 4$)$ according to hydrological profile. The figure includes monitored wells (red dots), reservoirs and barriers (brown bars), the boundary of the alluvial aquifer (orange line), main areas of irrigated farmland (green and blue frames) and an insert showing the pilot area traversed by the Forquilha river (blue arrows), the location of piezometers (yellow crosses) and irrigated crops (green polygons)

of the water table $(\mathrm{H})$ and the electrical conductivity (EC) in 4 reservoirs and 20 piezometers were monitored weekly during the rainy season and monthly during the dry season for 75 months (September 2000 to December 2006).

Sampling and monitoring campaigns were carried out during the release of water from the Riacho Verde reservoir in 2005 and 2006. A 1.500 by 250meter wide pilot area in Section 3 b (FIG. 2) was chosen to study the interaction between river and aquifer and the relation between the saturated and unsaturated zone.

In this study, residual alkalinity (AlkR), chloride $\left(\mathrm{Cl}^{-}\right)$and $\mathrm{EC}$ were used as tracers to monitor the contribution of different water bodies to the surface runoff (RIBOLZI et al, 1997). AlkR was calculated with the formula:

$$
\mathrm{AlkR}=\mathrm{AlkC}-\left(\left[\mathrm{Ca}^{+2}\right]+\left[\mathrm{Mg}^{2+}\right]\right)
$$

where AlkR, AlkC (carbonate alkalinity),

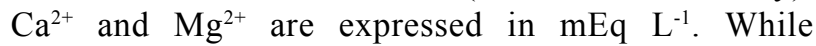
the components $\mathrm{AlkC}, \mathrm{Ca}^{2+}$ and $\mathrm{Mg}^{2+}$ are strongly influenced by patterns of precipitation and dissolution, residual alkalinity is relatively conservative (RIBOLZI et al., 1996). Chloride is also an excellent conservative solute tracer.

\section{Results and discussion}

Hydrosaline dynamics of the alluvial aquifer - Whereas the hydrological dynamics of the alluvial aquifer are clearly determined by seasonal runoff patterns, the saline dynamics are less evident (FIG. 3), suggesting the contribution of other factors, including local permeability, as demonstrated in other studies (MONTENEGRO; MONTENEGRO, 2006), and external structures (unsaturated zone and crystalline bedrock).

The lowering of the water table in drought periods and the rise in water salinity during the rainy season led farmers and residents downstream from the Riacho Verde reservoir, especially in Section 3 (FIG. 2), to initiate a sociopolitical process for the release of water. During the drought of 1998, the first documented release of water occurred with the purpose of making perennial a reach of the 
Forquilha river at a time when the water table in the alluvial aquifer was particularly low. The event triggered a heated political conflict between the communities downstream and the communities settled upstream on the shores of the reservoir. The lack of efficient communication and of a forum of negotiation between upstream and downstream stakeholders was the main obstacle to successful conflict prevention and management.

Beginning in 1998, the development of the use of groundwater for irrigation led to an increase in social pressure on local political leaders, demanding the recharge of downstream aquifers. However, the complete refilling of the Riacho Verde reservoir by heavy rainfalls in 2004 made conflict-free water release possible from 2004 to 2007.

A survey carried out among farmers showed that in the period covered by the study the main reason for requesting water release was first, from 2000 to 2004 , related to low water table levels and subsequently, from 2005 to 2006, to high values of groundwater salinity. This is supported by collected data ( $\mathrm{H}$ and $\mathrm{EC})$ : in the period 2003-2005. Each year, the first request for water release occurred when EC reached $0,9 \mathrm{dS} \mathrm{m}^{-1}$ (FIG. 3). In 2005, when the first request was made, aquifers were still charged $\left(\mathrm{H}-\mathrm{H}_{\text {riv }}\right.$ close to zero). The increase in EC observed after the recharge of 2004 made the farmers aware of the negative impact of irrigation using brackish water. Therefore, in 2005 the strategy was changed, it was asked to maintain perennial the flow in the riverbed to ensure supply of low-salinity water for irrigation.

Hence, the release of water from the Riacho Verde reservoir is an essential component in the local irrigation strategy, depending on the physical condition of the aquifer (groundwater level, salinity) and on anthropic factors (sociopolitical and agricultural activity).

The monitoring of the water resources (reservoir and aquifers) at the time of water release from Riacho Verde in 2003, 2004 and 2005 shows Section 1 (closest to the reservoir) to be the most strongly impacted with regard to $\mathrm{H}$ and $\mathrm{EC}$ (FIG. 2). In Section 2, where $\mathrm{H} \approx \mathrm{H}_{\text {riv }}$ before the release, EC remained unchanged in spite of rising groundwater levels (P51, near the river), indicating that little water flowed from the river into the aquifer (the hydraulic gradient between river and aquifer is almost zero). In Section 3, the release of water rarely produces short-term effects because the volume of water is usually not sufficient to generate a flow in the river bed.

A hydrological mass balance was built for the aquifer recharge based on data from P27 (Section 1) (TAB. 1) and the following aquifer parameters: width
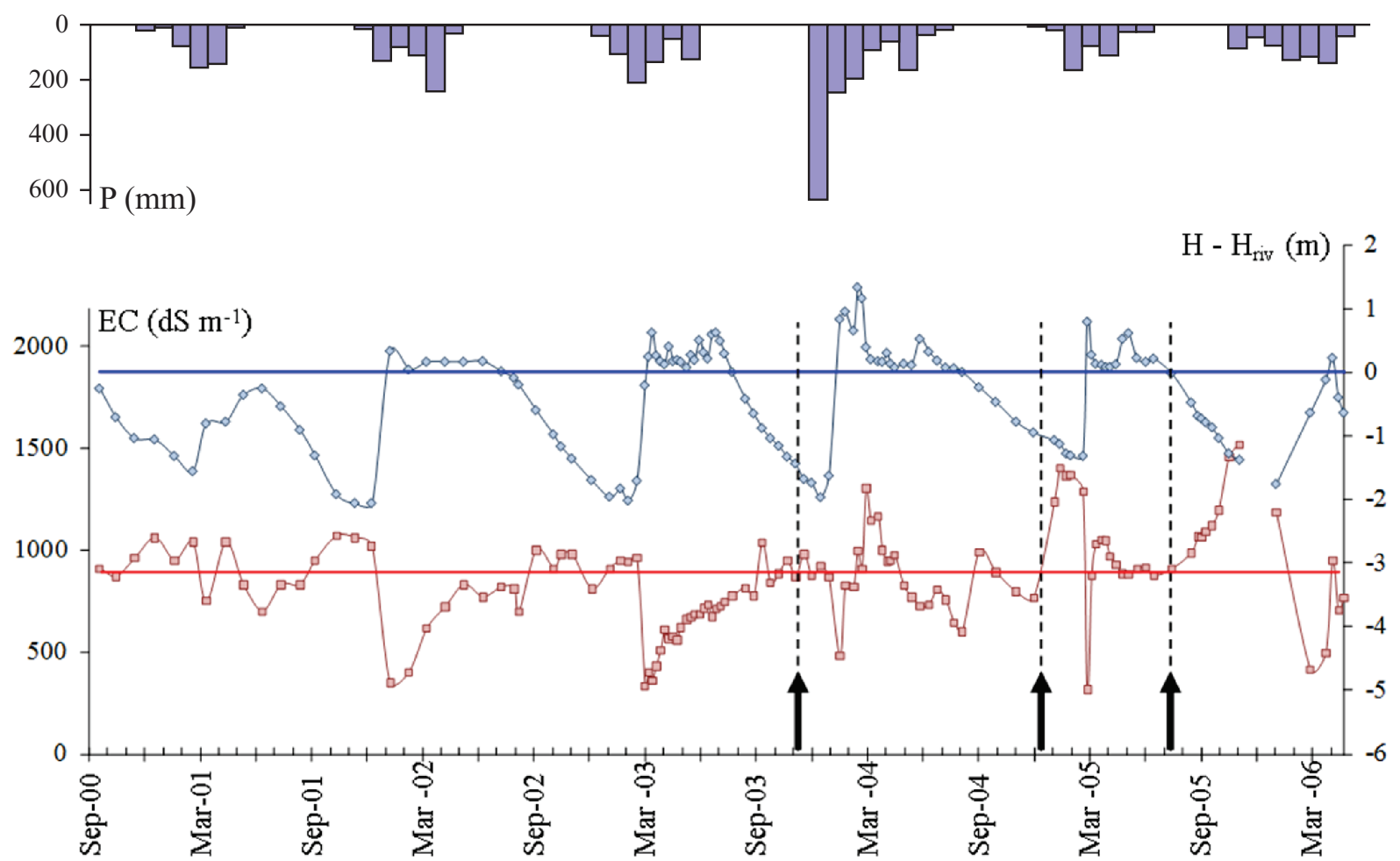

Figure 3 - Precipitation (blue bars), groundwater level (H) in relation to river bed level ( $\left.\mathrm{H}_{\text {riv }}\right)$ (blue plot) and EC (red plot) at P107, date of first request for water release each year (black arrows) in the period September 2000 - September 2006 
Table 1 - Electrical conductivity (EC) and ground water level (H) in the alluvial aquifer at P27 (Section 1) before, during and after water release from the Riacho Verde reservoir

\begin{tabular}{ccccc}
\hline & & Aquifer & \multirow{2}{*}{ Reservoir } \\
\hline Period / release & $19 / 09 / 2005$ (before) & $30 / 09 / 2005$ to 09/12/2005 (during) & $08 / 02 / 2006$ (after) & \\
\hline $\mathrm{H}(\mathrm{m})$ & $3.55\left(\mathrm{H}_{\mathrm{o}}\right)$ & $4.00\left(\mathrm{H}_{1}\right)$ & 3.35 & - \\
$\left.\mathrm{EC}(\mathrm{dS} \mathrm{m})^{-1}\right)$ & $1.00\left(\mathrm{EC}_{\mathrm{o}}\right)$ & $0.50\left(\mathrm{EC}_{1}\right)$ & $0.95\left(\mathrm{EC}_{2}\right)$ & $0.32\left(\mathrm{EC}_{\text {Reservoir }}\right)$ \\
\hline
\end{tabular}

$\ell=250 \mathrm{~m}$; river bed level $\mathrm{H}_{\text {riv }}=4 \mathrm{~m}$ (corresponding to the maximum water level during the release of the water); porosity $\rho_{\mathrm{e}}=10 \%$. The P27 piezometer is at $3 \mathrm{~km}$ downstream the reservoir and at $5 \mathrm{~m}$ from the river bed.

At the stage "before", the initial unitary volume of stored water is $\mathrm{Vo}_{\mathrm{o}}=\rho_{\mathrm{e}} \mathrm{H}_{\mathrm{o}} \ell$ of $89 \mathrm{~m}^{3}$ per meter of aquifer measured longitudinally. At stage "during", a $\mathrm{V}_{\text {Recharge }}$ volume of water is added $\mathrm{V}_{\text {Recharge }}=\rho_{\mathrm{e}}\left[\mathrm{H}_{\text {riv }}-\mathrm{H}_{\mathrm{o}}\right] \ell$ of 11 $\mathrm{m}^{3} / \mathrm{m}$, the water level in the aquifer is equal to the one in the river $\left(\mathrm{H}=\mathrm{H}_{\text {riv }}\right)$.

At the stage after, more than 5 months after the release, assuming a perfect mixture over the whole volume, the expected $\mathrm{EC}\left(\mathrm{EC}_{2}\right)$ may be calculated as:

$$
\mathrm{EC}_{2}^{\prime}=\frac{\left(\mathrm{V}_{0} \times \mathrm{EC}_{0}\right)+\left(\mathrm{V}_{\text {Recharge }} \times \mathrm{EC}_{\text {Recharge }}\right)}{\left(\mathrm{V}_{0}+\mathrm{V}_{\text {Recharge }}\right)} 0.92 \mathrm{dS} \mathrm{m}{ }^{-1}
$$

This figure of $0.92 \mathrm{dS} \mathrm{m}^{-1}$ is quite similar to the value of measured $\mathrm{EC}_{2}, 0.95 \mathrm{dS} \mathrm{m}^{-1}$ and corroborate the assumption of the perfect mixture of a volume $\mathrm{V}_{\text {Recharge }}$ with a $\mathrm{EC}$ of the reservoir with the $\mathrm{V}_{0}$ volume with an initial EC of $1 \mathrm{dS} \mathrm{m}^{-1}$.

The small value of $\mathrm{EC}_{1}\left(0.5 \mathrm{dS} \mathrm{cm} \mathrm{cm}^{-1}\right)$ measured during the release and the 2 to 3 months after the release may be explained by the fact that mixture was not yet achieved over the whole width of the aquifer. Assuming a perfect mixture, it is possible to estimate $\mathrm{V}_{0}^{\prime}$, that is, the volume with which $\mathrm{V}_{\text {Recharge }}$ was mixed to attain $\mathrm{EC}_{1}$ at the P27 piezometer.

Thus:

$$
\mathrm{V}_{0}^{\prime}=\frac{\left(\mathrm{EC}_{1}-\mathrm{EC}_{\mathrm{R}}\right) \times \mathrm{V}_{\text {Recharge }}}{\left(\mathrm{EC}_{0}-\mathrm{EC}_{1}\right)}=4 \mathrm{~m}^{3} / \mathrm{m}=5 \% \text { of } \mathrm{V}_{0}
$$

Based on this calculation, it may be assumed that recharge from surface runoff along the river bed in this section resulted in water mixture over a relatively limited area, corresponding to approximately $5 \%$ of the aquifer width; consequently, not all the aquifer was impacted by dilution during a period of the order of 1 to 3 months.
Now considering the whole aquifer, three elements of hydraulic infrastructure have a particularly direct influence on the hydrological dynamics of the Forquilha watershed:

- The Lagoa Cercada reservoir (FIG. 2), built in 2002 , charges the alluvial aquifer downstream by way of a permanent leakage, ensuring that the groundwater level remains at the level of the water in the river bed. The reservoir leakage has been estimated with a conceptual model to be $15 \mathrm{~L} \mathrm{~s}^{-1}$, later confirmed by measurement with a Parshall flume (2003) and by visual inspection $(2004,2005)$.

- Riacho Verde. The water from this reservoir has been released several times since 2004 to support farmers irrigating crops near P101 with water from the alluvial aquifer. Water was released periodically in the dry seasons of 2003, 2004 and 2005, and continuously in 2006 at variable flow rate and duration $\left(0\right.$ to $130 \mathrm{~L} \mathrm{~s}^{-1}$ for hours or even weeks). This water release accounts for the maintenance of the water table in the Forquilha river bed, as registered at $\mathrm{P} 60$, but not at $\mathrm{P} 101$ or $\mathrm{P} 133$ (except in early 2006), indicating surface runoff did not reach P101 (FIG. 2).

- Veneza, a barrier across the Forquilha river designed to impound water (up to $3 \times 10^{5} \mathrm{~m}^{3}$ ) temporarily during rainy periods. Streamflow is seen downstream from Veneza only after the impounded water reaches the level of the spillway. Consequently, the registered runoff volume was significantly smaller at P133 than at P101, especially in years with little rainfall (2001, 2005 and 2006). Only the greatest flood peaks observed at P60 or P101 were also reflected at P133 (FIG. 2).

Knowledge of the hydrological dynamics of different sections of the Forquilha watershed is necessary to subsidize interpretation, discussion and management of local water resources, especially with regard to the problem of salinity.

Water quality - Based on 160 analyses performed for this study and 372 analyses available in the literature (SILVA et al., 1999), the median values of the geochemical parameters of different water bodies (reservoirs, and alluvial aquifers in the absence or presence of surface runoff in the river bed) were compared using the Mann-Whitney test. The level of statistical 

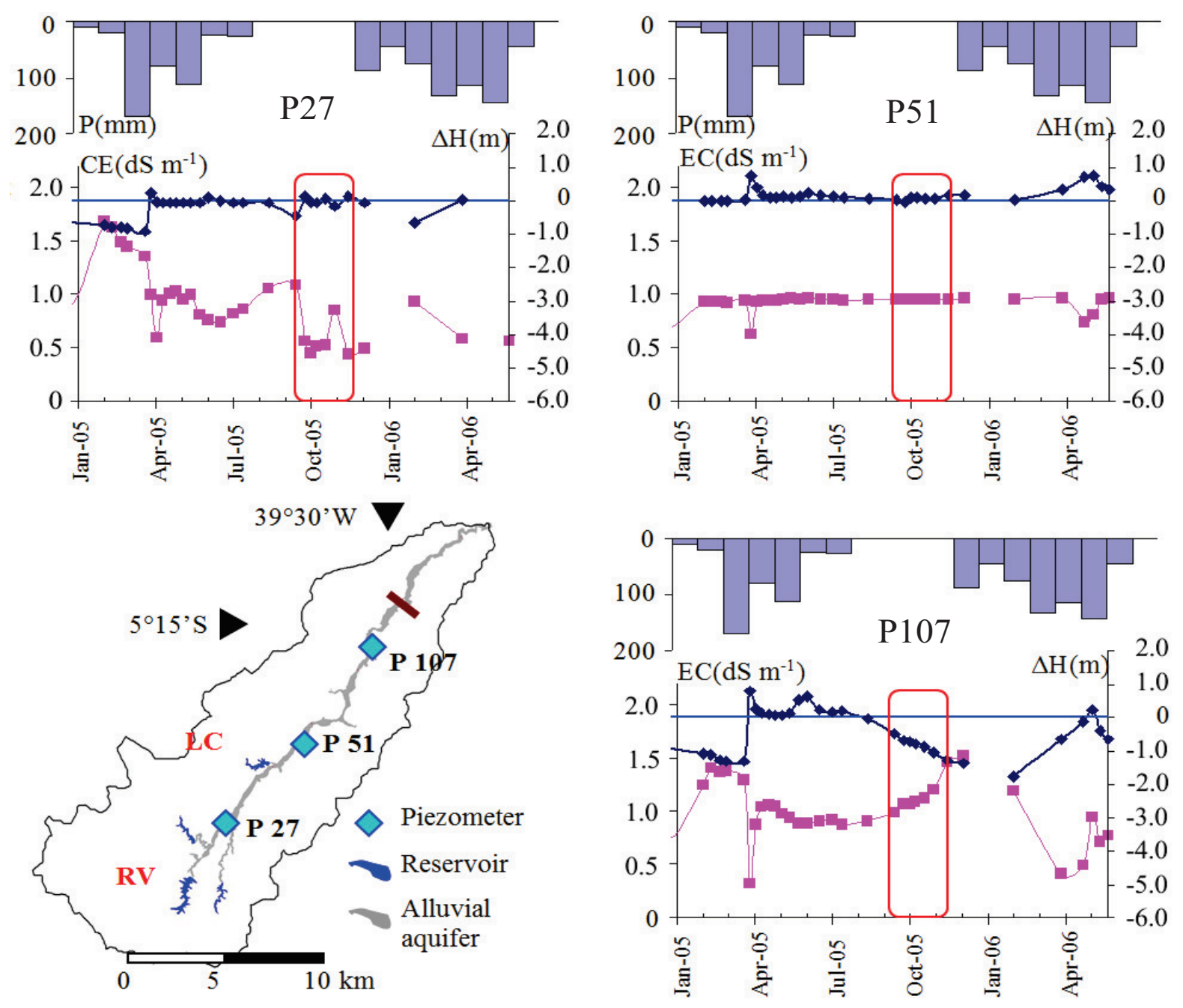

Figure 4 - Influence of water release from the Riacho Verde reservoir on EC (pink plot) and the level of the water table $\Delta H(\mathrm{~m})$ (dark blue plot) registered at three piezometers (P27, P51 and P107). As shown by pluviometry (blue bars), water release (red frame) occurred during the dry season

significance was set at $p<0,05$ (TAB. 2). The composition of the alluvial aquifers differed between runoff periods, as did the levels of alkalinity, chlorides, sodium and EC. The sodium absorption ratio (SAR) and the relation between SAR and EC of samples from different water bodies show that reservoirs (C1S1), alluvial aquifers (C2S1 to C3S1) and the crystalline bedrock (C3S1) have different salinity profiles and therefore different potential for irrigation.

Table 2 - Comparison of median values for water composition $\left(\mathrm{mol} \mathrm{m}^{-3}\right)$ and $\mathrm{EC}\left(\mathrm{dS} \mathrm{m}^{-1}\right) . \mathrm{N}$ is the number of samples, Alk is alkalinity, AlkR is residual alkalinity, the letters $(a, b, c, d)$ to the right of each numeric value indicate similarity between water sources

\begin{tabular}{ccccccc}
\hline & $\mathrm{N}$ & $\mathrm{Alk}^{*}$ & $\mathrm{Cl}$ & $\mathrm{Na}$ & $\mathrm{CE}$ & AlkR \\
\hline Reservoirs & 8 & $1,78 \mathrm{~A}$ & $1,00 \mathrm{a}$ & $0,86 \mathrm{a}$ & $0,29 \mathrm{a}$ & $-0,00$ \\
River & 13 & $4,36 \mathrm{bc}$ & $3,31 \mathrm{~b}$ & $4,32 \mathrm{~b}$ & $0,78 \mathrm{~b}$ & $-0,37$ \\
Aquifer (with runoff) & 49 & $4,69 \mathrm{~b}$ & $2,96 \mathrm{~b}$ & $4,88 \mathrm{bc}$ & $0,86 \mathrm{~b}$ & 0,28 \\
Aquifer (without runoff) & 47 & $5,94 \mathrm{c}$ & $5,09 \mathrm{c}$ & $5,10 \mathrm{c}$ & $1,10 \mathrm{a}$ & 0,47 \\
Crystalline bedrock $(*)$ & 376 & $5,69 \mathrm{c}$ & $21,2 \mathrm{~d}$ & $13,0 \mathrm{a}$ & $>2,5$ & $-9,34$ \\
\hline
\end{tabular}

* figures for the crystalline bedrock after (SILVA et al, 1999) 
After these measurements, residual alkalinity is negative for the crystalline bedrock and river water and positive for the alluvial aquifer.

Thus the use of alluvial aquifer water for irrigation represents a serious risk of soil alkalinization. However, in view of the spatial heterogeneity of the alluvial sediments and consequent spatial and temporal heterogeneity of the chemical composition of the water they contain, the determination of the actual risk of soil alkalinization should be based on individual analyses. Considering the preference of local farmers for micro-sprinkler systems and dripping irrigation, the high salinity and bicarbonate concentration also represent a risk for clogging drippers and drip tape holes.

Salt mass balance - The salt mass balance was determined for the pilot area based on data from P101-P113. The results for P101 (river bed), P111 (90m from the river) and P113 (190m from the river) are discussed below, but detailed data are only shown for P111 (FIG. 5). For each piezometer, the mass of dissolved salts ( $\mathrm{g} \mathrm{m}^{-2}$ aquifer) was calculated based on the level of the water table and the salt concentration. The measured and the calculated salt mass per square meter in the dry season were compared assuming a constant salt concentration equal to $\mathrm{C}_{\mathrm{o}}$ (concentration at the beginning of the drought season). The correlations were excellent $\left(\mathrm{R}^{2}>0,85\right)$, indicating the absence of a significant external contribution during the dry season.

In 2004, when the entire aquifer was submerged during an unusually heavy rainy season (return frequency $>20$ years), salinity increased significantly at P111 and P113. A delayed peak was observed at
P101 as well (FIG. 2). The level of salinity remained high at all three locations until the end of 2005.

The increase in salinity after the floods of 2004 may be accounted for by either contribution from the crystalline bedrock or leaching from the unsaturated zone. The difference in salt mass between pre-flood baseline values $\left(\mathrm{t}_{0}\right)$ and values 27 and 90 days after the flood $\left(t_{27}\right.$ and $\left.t_{90}\right)$ measured at the three piezometers makes it possible to calculate the amount of salt required to produce the observed increase (TAB. 3; FIG. 6). The balance was carried out to test the hypothesis that salinity increased after the flood of 2004 due to the leaching of salts accumulated by evaporation in the unsaturated zone since the previous peak flood.

The salinity of the groundwater near the river decreased due to dilution by direct infiltration of low-salinity $\left(0.07 \mathrm{~g} \mathrm{~L}^{-1}\right)$ runoff water along the river bed; that is the case of P101. On the contrary, the groundwater salinity farther from the aquifer (P111 and P113) increased considerably due to the leaching of 1 to $2 \mathrm{~kg} \mathrm{~m}^{-2}$ of salts (compare M values pre/post-flood in TAB. 3 ) from the unsaturated zone (hypothesis 1) or due to the discharge of saline water through crevices in the bedrock (hypothesis 2, FIG. 6). When the level of the river falls, the river-to-aquifer flow is reverted allowing saline water to drain into the river, explaining the salinity peak observed at P101. Ninety days after the flood, when the water level of the river and the aquifer was nearly the same, the salinity was similar at P101 and P111, but still differed at P113 due to the greater distance from the river. In an earlier study of the soils in this area (2002), a drainage test yielded a salt concentration of $3 \mathrm{~g} \mathrm{~L}^{-1}$ in leached water. This is even higher than the concentration considered in the present study (1.52 and $\left.2.04 \mathrm{~g} \mathrm{~L}^{-1}\right)$.

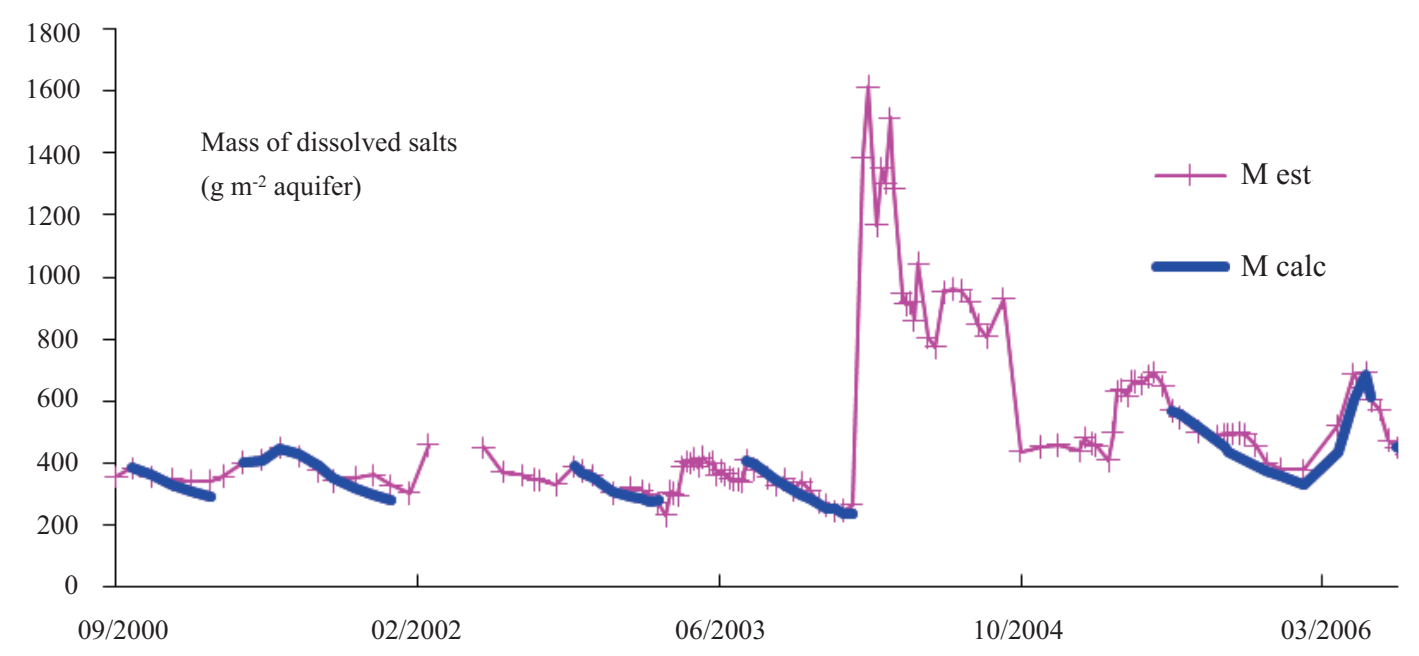

Figure 5 - Mass of dissolved salts $\left(\mathrm{g} \mathrm{m}^{-2}\right.$ aquifer $)$ at P111 estimated from measurements $\left(\mathrm{M}_{\mathrm{est}}\right)$ in periods without runoff and calculated $\left(\mathrm{M}_{\text {calc }}\right)$ assuming a constant concentration 
Table 3 - Salt mass (M) expressed in $\mathrm{g} \mathrm{m}^{-2}$, salt concentration (C) expressed in $\mathrm{g} \mathrm{L}^{-1}$ and level of water table (H) expressed in $\mathrm{m}$, before $\left(\mathrm{t}_{0}\right)$ and 27 days after the flood $\left(\mathrm{t}_{27}\right)$ at P101, P111 and P113, and salt concentration of recharge water in $\mathrm{g} \mathrm{L}^{-1}$ required to obtain the concentrations observed after the flood

\begin{tabular}{ccccc}
\hline Caracteristics & period & P101 & P111 & P113 \\
\hline \multirow{2}{*}{$\mathrm{M}\left(\mathrm{g} \mathrm{m}^{-2}\right)$} & pre-flood & 526 & 268 & 617 \\
& post-flood & $546\left(^{*}\right)$ & 1613 & 1611 \\
\hline \multirow{2}{*}{$\mathrm{H}(\mathrm{m})$} & pre-flood & 3.48 & 2,15 & 3.55 \\
& post-flood & $4.95\left(^{*}\right)$ & 5.45 & 6.83 \\
\hline $\mathrm{C}\left(\mathrm{g} \mathrm{L}^{-1}\right)$ & pre-flood & 0.76 & 0.62 & 0.87 \\
\hline Salt concentration of recharge water $\left(\mathrm{g} \mathrm{L}^{-1}\right)$ & post-flood & $0.55\left(^{*}\right)$ & 1.5 & 1.2 \\
\hline
\end{tabular}

$\left.{ }^{*}\right)$ observation made at $\mathrm{t}+62$ days; Our conceptual model is presented in Figure 6

$\mathrm{t}=0$

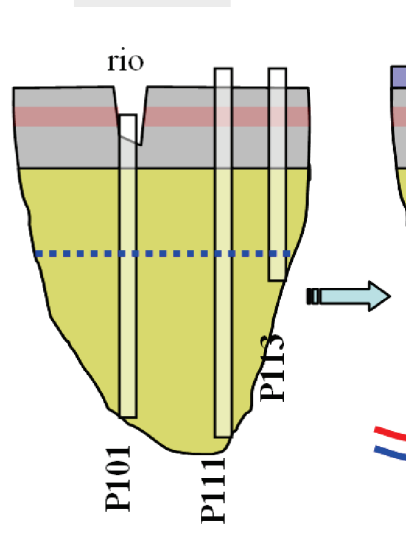

....... Piezometric level

$\longrightarrow$ Salt flux

$\longrightarrow$ Water flux $\mathrm{t}=0+$

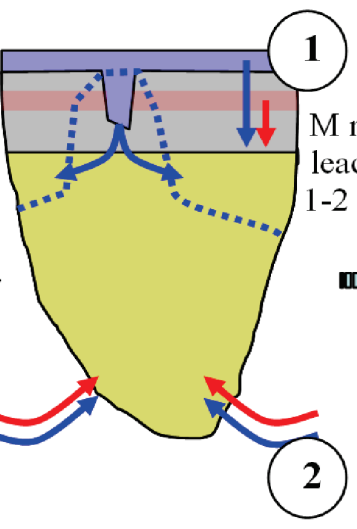

2)

Highly saline water

$\left(2 \mathrm{~g} \mathrm{~L}^{-1}\right)$ $t=90$ days

$\mathrm{t}=27$ days
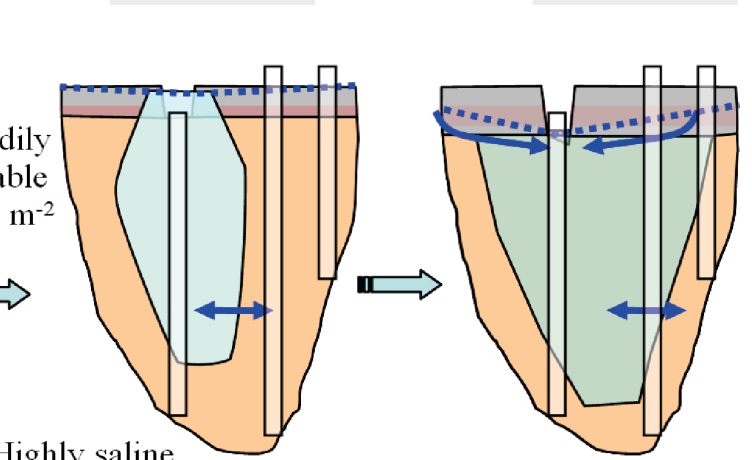

Water salinity $\left(\mathrm{g} \mathrm{L}^{-1}\right)$

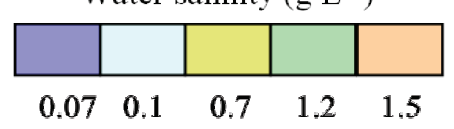

Figure 6 - Conceptual model of two possible explanations for the increase in salinity observed after the flood of 2004: (1) contribution from the crystalline bedrock, and (2) leaching from the unsaturated zone

Previous studies on the Forquilha watershed (BURTE; SCHRADER, 1998; CHAPUIS, 2001) showed that only part of the salts contained in irrigation water is consumed by crops (mainly $\mathrm{Ca}^{2+}$ and $\mathrm{K}^{+}$). The remaining salts are retained in the unsaturated zone from where they are eventually leached, in support of our conceptual model. This is one of the essential obstacles to irrigated agriculture in semi-arid environments (BURKHALTER et al., 2005).

\section{Conclusion}

1. The proposed model of hydrosaline dynamics of the aquifers in the Forquilha watershed can explain fluctuations in the levels of salinity observed at different piezometers after rain floods as a result of either discharge from the crystalline bedrock or leaching from the unsaturated zone. Irrigation leads to a redistribution of salts from the saturated to the unsaturated zone of the alluvial aquifer, causing accumulation. The water in these aquifers may be used for irrigation, but represents a risk of soil salinization and alkalinization;

2. Further studies are needed to evaluate the risk of soil alkalinization in other geological and geomorphological contexts and to monitor fluctuations in saturated and unsaturated zones at high frequency (at least hourly). In fact, the hydrological dynamics of small alluvial aquifers are strongly dependent on local events occurring at a 
greater than daily frequency, such as floods, evaporation (BORONINA et al., 2005) and anthropic activities;

3. Integrated management of surface and underground water resources in the Forquilha watershed can help control irrigation water quality (salinity and residual alcalinity), especially if the water is retrieved from shallow wells near the river bed, thereby rationalizing the use of reservoir water and minimizing losses from evaporation (BURTE et al., 2009).

\section{Acknowledgments}

The authors would like to thank CIRAD, Funceme, $\mathrm{CNPq}$ and Capes-Cofecub for their financial support.

\section{References}

ALVES, J. M. B. et al. Mecanismos atmosféricos associados à ocorrência de precipitação intensa sobre o Nordeste do Brasil durante Janeiro/2004. Revista Brasileira de Meteorologia, v. 21, n. 01, p. $1-21,2006$.

AUDRY, P.; SUASSUNA, J. A salinidade das águas disponíveis para a pequena irrigação no sertão nordestino : caracterização, variação sazonal, limitações de uso. Recife: CNPq, 1995. 128 p.

BASTOS, D. C. O. et al. Avaliação de alternativa de irrigação suplementar com água moderadamente salina em vale aluvial no semi-árido: experimentação e modelagem. Revista Brasileira de Recursos Hídricos , v. 14, n. 03, p. 27-36, 2009.

BORONINA, A.; GOLUBEV, S.; BALDERAR, W. Estimation of actual evapotranspiration from an alluvial aquifer of the Kouris catchment (Cyprus) using continuous streamflow records. Hydrological Processes, v. 19, n. 20, p. 4055-4068, 2005.

BURKHALTER, J. P.; GATES, T. K. Agroecological impacts from salinization and waterlogging in an irrigated river valley. Journal of Irrigation and Drainage Engineering-Asce, v. 131, n. 02, p. 197-209, 2005.

BURTE, J. et al. Human impacts on components of hydrological balance in an alluvial aquifer in the semiarid Northeast, Brazil. Hydrological Sciences Journal-Journal Des Sciences Hydrologiques, v. 50, n. 01, p. 95-110, 2005.

BURTE, J. et al. Simulations of multipurpose water availability in a semi-arid catchment under different management strategies. Agricultural Water Management, v. 96, n. 08, p. 1181-1190, 2009.

BURTE, J.; SCHRADER, G. O. Análise do potencial agrícola e dos recursos hídricos do Vale do Forquilha. Fortaleza: UECE. 1998. 23 p.. (Report)

CADIER, E. Hydrologie des petits bassins du Nordeste Bresilien semi-aride: typologie des bassins et transposition ecoulements annuels Small watershed hydrology in semiarid north-eastern Brazil: basin typology and transposition of annual runoff data. Journal of Hydrology, v. 182, n. 1-4, p. 117-141, 1996.

CHAPUIS, E. Influence de divers types et dosages de fertilisants chimiques et orgnaiques sur la productionde tomate cultivar SM 16. (2001). 90 f. Monografia. (Graduação em Agronomia tropical e desenvolvimento rural). ISTOM, Paris, 2001.

COUDRAIN-RIBSTEIN, A. et al. Is the evaporation from phreatic aquifers in arid zones independent of the soil characteristics? Comptes Rendus De L Academie Des Sciences Serie Ii Fascicule a-Sciences De La Terre Et Des Planetes, v. 326, n. 03, p. 159-165, 1998.

MONTENEGRO, A. A.; MONTENEGRO, S. M. Variabilidade espacial de classes de textura, salinidade e condutividade hidráulica de solos em planície aluvial. Revista Brasileira de Engenharia Agrícola e Ambiental, v. 10, n. 01, p. 30-37, 2006.

MONTENEGRO, S. G.. MONTENEGRO, A.; RAGAB, R. Improving agricultural water management in the semi-arid region of Brazil: experimental and modelling study. Irrigation Science, v. 28, n. 04, p. 301-316, 2010.

RIBOLZI, O. et al. Stream water regime change at autumn recharge on a Mediterranean farmed catchment using a natural tracer. Comptes Rendus De $\mathbf{L}$ Academie Des Sciences Serie Ii Fascicule a-Sciences De La Terre Et Des Planetes, v. 324, n. 12, p. 985-992, 1997.

RIBOLZI, O. et al. Comparison of hydrograph deconvolutions using residual alkalinity, chloride, and oxygen 18 as hydrochemical tracers. Water Resources Research, v. 32, n. 04 , p. 1051-1059, 1996.

SALES NETO, P. (Ed.) Estudo da salinidade das águas em pequenas bacias hidrográficas. Fortaleza: FUNCEME, 2002. 342 p.

SILVA, L. G. D. A. J. et al. Composição química de águas do cristalino do Nordeste brasileiro. Revista Brasileira de Engenharia Agrícola e Ambiental, v. 3, n. 01, p. 11-17, 1999. 